\title{
MYCORRHIZATION STIMULANT IN SOYBEAN ASSOCIATED WITH PHOSPHATE FERTILIZATION IN OXISOLS ${ }^{1}$
}

\author{
FABRÍCIO RIBEIRO ANDRADE ${ }^{2 *}$, JÚLIO CÉSAR AZEVEDO NÓBREGA ${ }^{3}$, RAFAELA SIMÃO ABRAHÃO \\ NÓBREGA ${ }^{3}$, JOSÉ FERREIRA LUSTOSA FILHO ${ }^{4}$, ALAN MARIO ZUFFO $^{5}$, FATIMA MARIA DE SOUZA \\ MOREIRA $^{4}$
}

\begin{abstract}
The use of stimulants in the establishment of arbuscular mycorrhizal fungi has great potential in contributing to $\mathrm{P}$ uptake by plants. This study aimed to evaluate the effect of isoflavonoid formononetin as mycorrhization stimulant on soybean associated with phosphate fertilizer in Oxisols with intermediate (OPi) and low (OPl) phosphorus availability, in the Cerrado region of Piauí. The experiment in each soil consisted of randomized blocks design in a $4 \times 4$ factorial scheme, with four replications. The treatments comprised of four phosphorus doses $\left(0,26.66,40\right.$ and $\left.80 \mathrm{~kg} \mathrm{ha}^{-1} \mathrm{P}_{2} \mathrm{O}_{5}\right)$, and four isoflavonoid formononetin doses $(0,0.5,0.9$ and $1.8 \mathrm{~g} \mathrm{~kg}^{-1}$ soybean seeds). The variables evaluated were soybean growth, yield, nodulation and mycorrhizal colonization rate. With the exception of mycorrhizal colonization rate in OPi, plant height and number of pods per plant in OP1, the other variables were not affected by the application of isoflavonoid formononetin, in both soils. Yield linearly increased with increase in the phosphorus doses in OPl, and presented agronomic efficiency of $\sim 15 \mathrm{~kg} \mathrm{ha}^{-1}$ grain for each $\mathrm{kg} \mathrm{ha}^{-1} \mathrm{P}_{2} \mathrm{O}_{5}$ applied to the soil.
\end{abstract}

Keywords: Glycine $\max ($ L.). Phosphorus. Arbuscular mycorrhizal fungi.

\section{ESTIMULANTE DE MICORRIZAÇÃO EM SOJA ASSOCIADO À ADUBAÇÃO FOSFATADA EM LATOSSOLOS}

RESUMO - O uso de estimulantes para o estabelecimento de fungos micorrízicos arbusculares tem grande potencial em contribuir para a absorção de P pelas plantas. Objetivou-se avaliar a eficácia do isoflavonóide formononetina como estimulante da micorrização na cultura da soja, associada a adubação fosfatada, em dois Latossolos com teores de fósforo disponível médio ( $\mathrm{LPm})$ e baixo ( $\mathrm{LPb}$ ) no Cerrado piauiense. O delineamento experimental em cada solo foi em blocos casualizados no esquema fatorial $4 \times 4$, com quatro repetições. Os tratamentos foram constituídos por quatro doses de fósforo $\left(0 ; 26,66 ; 40\right.$ e $80 \mathrm{~kg} \mathrm{ha}^{-1}$ de $\left.\mathrm{P}_{2} \mathrm{O}_{5}\right)$ e quatro doses do isoflavonóide formononetina $\left(0 ; 0,5 ; 0,9\right.$ e $1,8 \mathrm{~g} \mathrm{~kg}^{-1}$ de semente de soja). As variáveis avaliadas foram, o crescimento, a produção, a nodulação e taxa de colonização micorrízica da soja. Com exceção da taxa de colonização micorrízica no LPm, altura e número de vagens por planta de soja no LPb, as demais variáveis, não foram influenciados pela aplicação do isoflavonóide formononetina, em ambos os solos. A produtividade cresceu linearmente ao incremento das doses de fósforo no $\mathrm{LPb}$, apresentando uma eficiência agronômica de $\sim 15 \mathrm{~kg} \mathrm{ha}^{-1}$ de grãos para cada $\mathrm{kg} \mathrm{ha}^{-1}$ de $\mathrm{P}_{2} \mathrm{O}_{5}$ aplicado no solo.

Palavras-chave: Glycine max (L.). Fósforo. Fungos micorrízicos arbusculares.

\footnotetext{
${ }^{*}$ Corresponding author

${ }^{1}$ Received for publication in 02/16/2017; accepted in 03/08/2018.

${ }^{2}$ Department of Agronomy, Instituto Federal de Educação, Ciência e Tecnologia de Mato Grosso, Juína, MT, Brazil; fabricio.andrade@jna.ifmt.edu.br-ORCID: 0000-0003-1865-6502.

${ }^{3}$ Center of Agrarian Sciences, Environmental and Biological, Universidade Federal do Recôncavo da Bahia, Cruz das Almas, BA, Brazil; juliocnobrega@gmail.com - ORCID: 0000-0002-2726-8205, rafaela.nobrega@gmail.com - ORCID: 0000-0002-6717-1344.

${ }^{4}$ Department of Soil Science, Universidade Federal de Lavras, Lavras, MG, Brazil; filhoze04@hotmail.com - ORCID: 0000-0001-69011718,fmoreira@dcs.ufla.br-ORCID: 0000-0003-0159-5811.

${ }^{5}$ Sustainability in Agriculture, Universidade Estadual de Mato Grosso do Sul, Cassilândia, MS, Brazil; alan_zuffo@hotmail.com - ORCID: 0000-0001-9704-5325.
} 


\section{INTRODUCTION}

Soybean [Glycine $\max (\mathrm{L}$.$) Merrill] is one of$ the most important crops in the Cerrado region of Piauí and has been indicated in the national scenario as a result of its tremendous grain yield potential (PONTES et al., 2017). Agricultural productivity in tropical regions such as the Brazilian Cerrado, has been limited by the low natural fertility of the soil (LOPES; GUILHERME, 2016). In these soils, phosphorus $(\mathrm{P})$ deficiency is due to the fixation by 1:1 clay and iron and aluminum oxides (NOVAIS; SMYTH, 1999; ABDALA et al., 2015; LOPES; GUILHERME, 2016). Therefore, the implementation of technologies aiming to increase efficiency in the use of $\mathrm{P}$ by plants is important for the cultivation of this agro-ecosystem (TEIXEIRA et al., 2016).

In plants, $P$ plays an important role in photosynthesis, respiration, energy storage and transfer, and consequently acts in cell division and growth, among other processes of plant development (HAWKESFORD et al., 2012). Thus, P deficiency causes reduction in shoots by limitation of the number and expansion of the leaves, shoots branching, reduction in carbon assimilation rate, and acceleration of leaf senescence (HAWKESFORD et al., 2012; SINGH; REDDY, 2015), which explains the low production of biomass of plants cultivated in the absence of $\mathrm{P}_{2} \mathrm{O}_{5}$.

The management of mycorrhizal symbiosis in the improvement of $\mathrm{P}$ nutrition is an alternative to be taken into account, due to the stimuli relevant to plant growth (NOURI et al., 2014), which are attributed to arbuscular mycorrhizal fungi (AMF). Thus, due to the exploitation of a greater soil amount and capacity of hyphae to absorb $\mathrm{P}$ at low concentrations (SMITH et al., 2011), AMF favors plant growth in low availability conditions of this element, contributing to $80 \%$ of $\mathrm{P}$ absorption (MARSCHNER; DELL, 1994).

The technological development for commercial use of AMF has been quite limited, since they are obligate biotrophic (BERRUTI et al., 2016). However, the use of stimulants to establish native $\mathrm{AMF}$ in roots has great potential in extensive agriculture. Ribeiro et al. (2016) evaluated field application of isoflavonoid in soils with different $\mathrm{P}$ doses, and concluded that formononetin isoflavonoid provided greater symbiosis between plants and mycorrhizal fungi, increasing colonization and maximizing the benefits they provide to plants. It is noteworthy that the use of formononetin has promoted grain yield in several crops, such as beans (LAMBAIS; RÍOS-RUIZ; ANDRADE, 2003), potato (DAVIES; CALDERON; HUAMAN, 2005) and soybean (CORDEIRO et al., 2015) in greenhouse condition. Thus, similar responses are expected in field conditions after the application of AMF stimulants.

It should be noted that mycorrhization management cannot be a substitute for phosphate fertilizer, since crops require high $\mathrm{P}$ doses. However, it may contribute to improvement of the efficiency of the fertilizer.

The objective of this study was to evaluate the effect of isoflavonoid formononetin as mycorrhization stimulant on soybean associated with different $\mathrm{P}_{2} \mathrm{O}_{5}$ doses in two Oxisols at the Cerrado region of Piauí.

\section{MATERIAL AND METHODS}

Two field experiments were conducted using soybean in the Cerrado region of Piauí, in two Oxisols (Latossolo Amarelo according to the Brazilian classification system): one with intermediate initial $\mathrm{P}$ content (OPi) and another with low $\mathrm{P}$ content (OPl). The first experiment was performed at Novo Horizonte farm, in the municipality of Monte Alegre, PI (lat. 09²19'21"S;

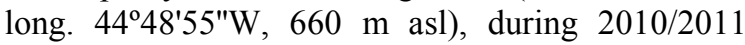
harvest. The initial $\mathrm{P}$ content was classified as intermediate (Table 1), according to CFSEMG (1999). The second experiment was carried out at Sabiá farm, municipality of Currais, PI (lat.

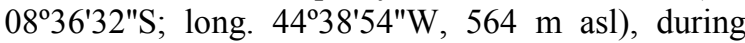
2011/2012 harvest. The initial $P$ content was classified as low (Table 1), according to CFSEMG (1999).

Table 1. Chemical and physical attributes and spore density in Oxisol, with intermediate $\mathrm{P}$ content (OPi) and low $\mathrm{P}$ content (OPl).

\begin{tabular}{|c|c|c|c|c|c|c|c|c|c|c|c|c|c|c|c|}
\hline Soil & $\begin{array}{c}\mathrm{pH} \\
\mathrm{H}_{2} \mathrm{O}\end{array}$ & $\begin{array}{l}\mathrm{OM} \\
\mathrm{g} \mathrm{kg}^{-1}\end{array}$ & $\mathrm{Ca}^{2+}$ & $\mathrm{Mg}^{2+}$ & $\begin{array}{l}\mathrm{Al}^{3+} \\
---\mathrm{cmc}^{3+}\end{array}$ & $\begin{array}{l}\mathrm{H}+\mathrm{Al} \\
\mathrm{l}_{\mathrm{c}} \mathrm{dm}^{-3}-\end{array}$ & SB & CEC & $\begin{array}{l}\mathrm{P} \\
\mathrm{mg}\end{array}$ & $\begin{array}{l}\mathrm{K}^{+} \\
\mathrm{m}^{-3}\end{array}$ & $\begin{array}{l}\mathrm{V} \\
\%\end{array}$ & $\begin{array}{c}\text { SD } \\
\mathrm{N}^{0} / 50 \mathrm{~mL}^{-1}\end{array}$ & Clay & $\begin{array}{l}\text { Silt } \\
\mathrm{g} \mathrm{kg}^{-1}-\end{array}$ & Sand \\
\hline OPi & 5.8 & 26.5 & 2.6 & 0.6 & 0.0 & 2.6 & 2.4 & 5.0 & 20 & 34 & 48.0 & 286 & 264 & 67 & 669 \\
\hline OP1 & 5.3 & 21.3 & 1.2 & 0.40 & 0.3 & 3.8 & 1.7 & 5.5 & 6.9 & 23 & 30.3 & 115 & 188 & 50 & 762 \\
\hline
\end{tabular}

$\mathrm{H}+\mathrm{Al}$ is potential acidity; SB is sum of bases; CEC is cation exchange capacity; OM is organic matter; V is base saturation; SD is spore density of arbuscular mycorrhizal fungi in $50 \mathrm{~mL}$ soil. 
According to Köppen (1931), the local climate is classified as Aw tropical, with two well defined seasons: dry season, from May to September, and rainy season, from October to April. Figure 1 shows the rainfall and temperature during the experiments.

The experiment in each soil is comprised of randomized blocks design with four replications and 16 treatments, in a factorial $4 \times 4$. The factors consisted of four $\mathrm{P}$ doses $(0,26.66,40$ and $80 \mathrm{~kg} \mathrm{ha}^{-1} \mathrm{P}_{2} \mathrm{O}_{5}$ ), and four doses of the isoflavonoid formononetin (0, 0.45, 0.9 and $1.8 \mathrm{~g} \mathrm{~kg}^{-1}$ seeds), formulated like the commercial product Myconate ${ }^{\circledR}$ (7-hydroxy, 4'-methoxy-isoflavone). For P doses, the values correspond to the application of $0,25,50$ and $100 \%$ of the recommended dose for intermediate initial $\mathrm{P}$ in soil, whereas for doses of isoflavonoid formononetin, the values correspond to the application of $0,25,50$ and $100 \%$ of the recommended doses of $77.28 \mathrm{~g} \mathrm{ha}^{-1}$ according to the manufacturers' recommendations (Plant Health Care). Super simple phosphate fertilizer $\left(18 \% \mathrm{P}_{2} \mathrm{O}_{5}\right)$ was used. Each plot was $6 \mathrm{~m}$ long and $3 \mathrm{~m}$ wide, with planting rows spaced $0.50 \mathrm{~m}$ apart, and the area of each plot was $18 \mathrm{~m}^{2}(6 \times 3 \mathrm{~m})$. The three central rows were considered as useful plot, excluding $1 \mathrm{~m}$ of each extremity.

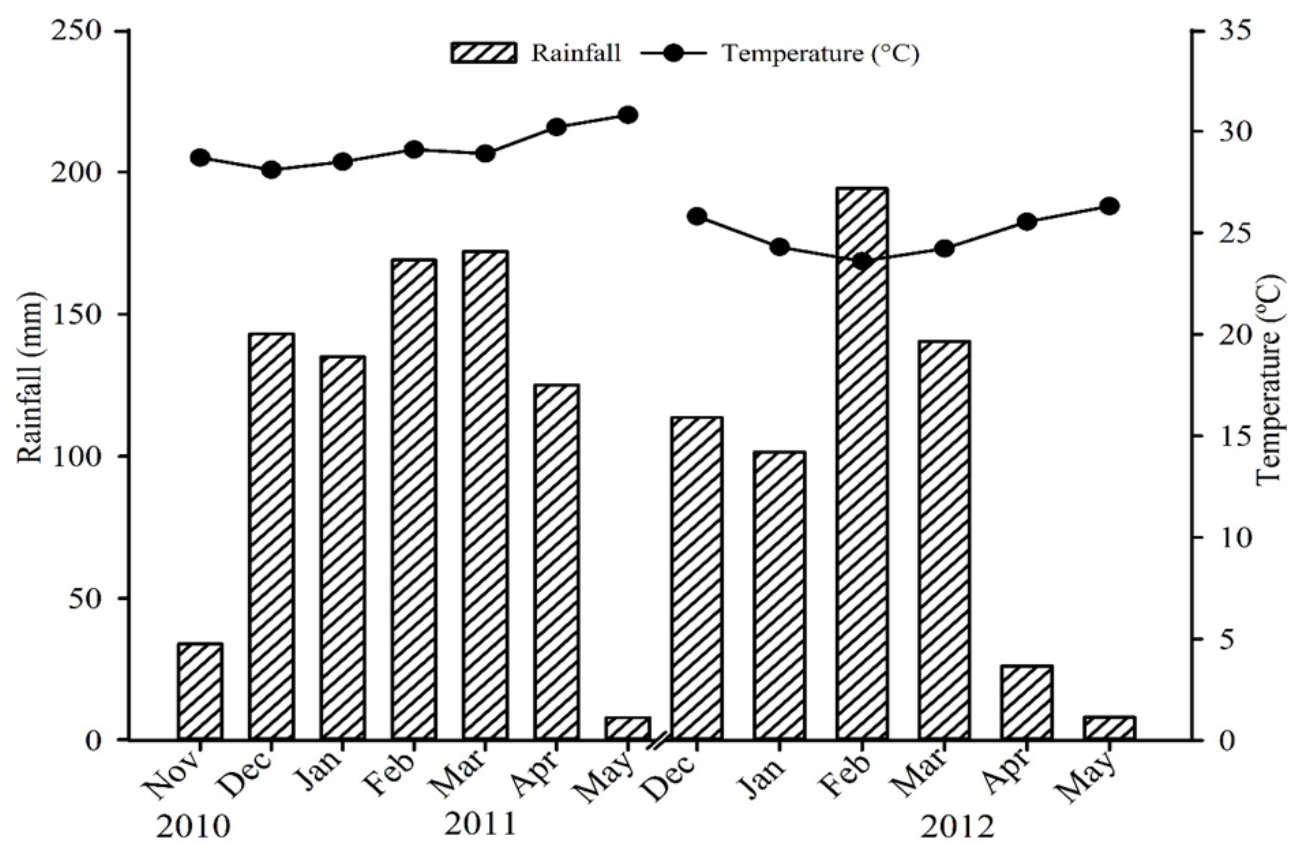

Figure 1. Average air temperature and accumulated rainfall in Bom Jesus, PI and in farm União - Currais, PI, similar to Sabiá, during experiments in the years, 2010 to 2012.

The soybean cultivar used was M-soy 8766 $\mathrm{RR}$, of late cycle and determinate growth, recommended for a Cerrado opening area with intermediate and low fertility soil. Seeds were treated with insecticide fipronil + fungicides pyraclostrobin and tiofanato metílico (Standak Top ${ }^{\mathbb{B}}$ ), and at the time of planting, they were inoculated with Bradyrhizobium japonicum, SEMIA 5079 and 5080 strains $\left(5.0 \times 10^{9}\right.$ viable cells $\left.\mathrm{mL}^{-1}\right)$ at the dose of $2 \mathrm{~mL} \mathrm{~kg}^{-1}$ seed, and subsequently, isoflavonoid doses were applied. Before the soybean seeding in both years, glyphosate herbicide was applied at a rate of $1,080 \mathrm{~g} \mathrm{ha}^{-1}$ a.e. to eliminate weeds. Weeds control at post-emergence was carried out with soybean at the trifoliate stage (V3), using glyphosate at a rate of $1,080 \mathrm{~g} \mathrm{ha}^{-1}$ a.e.

Potassium fertilization in OPi consisted of $80 \mathrm{~kg} \mathrm{ha}^{-1} \mathrm{~K}_{2} \mathrm{O}$ applied in the planting row. In OPl, $130 \mathrm{~kg} \mathrm{ha}^{-1} \mathrm{~K}_{2} \mathrm{O}$ was used, where $80 \mathrm{~kg}$ was applied in the planting row and the remaining was applied in topdressing when the crop was between phenological stages V4 and V5. Pest control was carried out at phenological stages V3, V6 and R2, using flubenzurom insecticide $\left(\mathrm{Nomolt}^{\circledR}\right)$ at a rate of $22.5 \mathrm{~g} \mathrm{ha}^{-1}$ a.e., for stinkbugs control, and permethrin was added to the last application (Pounce $384 \mathrm{CE}^{\circledR}$ ) at a rate of 49.9 gha $^{-1}$ a.e. Disease control was performed with the combined application of carbendazim and azoxystrobin + cyproconazole $\left(\right.$ Carbendazim $^{\circledR}$ and Priori Extra ${ }^{\circledR}$ ), in a mixture, at the phenological stage $\mathrm{R} 1$, and at 21 and 35 days after the first application, at a rate of 400 and 84 gha $^{-1}$ a.e., respectively.

The soybean plant stand in the useful area of the plot was evaluated 14 and 28 days after emergence. When the crop was at the phenological stage R1, plant height, shoot dry biomass, relative chlorophyll content, leaf $\mathrm{P}$ content, number of nodules per plant, nodules fresh weight, nodules dry weight and mycorrhizal colonization rate were measured. The relative chlorophyll content was determined using a portable Clorofilog CFL 1030 
Falker device. For sampling, the third fully developed trifoliate was used, from the apex to the base (diagnostic leaf), by sampling three trifoliates per plot.

Leaf $\mathrm{P}$ content was determined by collecting the diagnostic leaf in 10 plants of each plot. This material was dried in a forced air circulation oven at $60^{\circ} \mathrm{C}$ for $72 \mathrm{~h}$ and ground in a Willey mill equipped with a 40 mesh sieve. To obtain the leaf $P$ content, the tissues were digested using the nitropercloric digestion method and the determination was done by the molybdate blue method (MURPHY; RILEY, 1962). Shoot dry biomass, plant height, number of nodules per plant, fresh and dry weight of nodules, as well as mycorrhizal colonization rate were determined using five plants per plot. Plant height was determined by direct measurement with the aid of a graduated metric tape in centimeters and nodules fresh weight after count was weighed in a precision scale balance. The dry biomass of plants shoots and nodules dry weight were obtained by drying the plants and nodules in a forced air circulation oven at $60^{\circ} \mathrm{C}$ for $72 \mathrm{~h}$ and followed by weighing in a precision scale balance.

To determine the mycorrhizal colonization rate, roots of plants were collected and washed with water, and stored in plastic flasks containing a solution of 5\% formaldehyde, 90\% ethanol and 5\% acetic acid (PHILLIPS; HAYMAN, 1970). Thereafter, one gram of fine roots was clarified using $5 \% \mathrm{KOH}$ solution for $30 \mathrm{~min}$. Then, the material was washed in tap water and shaken for four minutes in $1 \% \mathrm{HCl}$. Roots with fungal structures were subsequently stained with $0.05 \%(\mathrm{w} / \mathrm{v})$ trypan blue in lactoglycerol (1:1:1 lactic acid, glycerol and water) following procedures described by Phillips and Hayman (1970). To estimate the percentage of colonized roots, the grid-line intersect method described by Giovanetti and Mosse (1980) was used, followed by observation under a stereoscopic microscope.

At the end of the crop cycle, five plants were collected for evaluation of the number of pods and grains per plant and weight of a thousand grains. Afterwards, plants of the useful area of the plot were manually collected, mechanically threshed, standardized to $13 \%$ humidity and the grains yield $\left(\mathrm{kg} \mathrm{ha}^{-1}\right)$ was obtained. The grain harvest index was determined as follows:

$\mathrm{GHI}=$ grain yield $/$ grain yield + straw

The measured data were subjected to a variance analysis and in the case of significance ( $p=0.05)$, factors were subjected to polynomial regression analysis for the effect of individual factors (P or isoflavonoid formononetin doses) and multiple linear regression when there was interaction of these factors, by using the statistical software R 3.2.3, and ExpDes package (FERREIRA; CAVALCANTI; NOGUEIRA, 2013). In order to obtain homoscedasticity, data of shoot dry biomass weight, number of nodules, and nodules fresh and dry weight were transformed by the equation $(x+1)^{0.5}$. The values presented in tables and figures are the original means.

\section{RESULTS AND DISCUSSION}

Mycorrhizal colonization rate (Figure 2A) was influenced by the interaction between $\mathrm{P}_{2} \mathrm{O}_{5}$ doses and formononetin in the $\mathrm{OPi}$, demonstrating the positive influence of formononetin application, and the negative influence of high $\mathrm{P}_{2} \mathrm{O}_{5}$ doses, thereby corroborating the results of Cordeiro et al. (2015) in soybean cultivated in Oxisol with intermediate $\mathrm{P}$ content. Therefore, it should be noted that the use of high $\mathrm{P}$ doses reduces the stimulation of mycorrhizal colonization (BALZERGUE et al., 2013), since during the symbiotic association, the plant provides assimilates to the fungi (BAGO; PFEFFER; SHACHAR-HILL, 2000). However, in a condition of full availability of $\mathrm{P}$ in the soil, this relation is no longer advantageous for plant, since $\mathrm{P}$ uptake occurs without extra energy expenditure. Although, a mycorrhizal colonization was expected in soil with low P content, this did not occur. This may be related to the environmental factors and not only the $\mathrm{P}$ content since the colonization by AMF depends on both biotic and abiotic factors to stimulate the germination of spores and association with the roots of plants (SOUZA, 2015).

For plant height (Figure 2B), there was interaction between $\mathrm{P}_{2} \mathrm{O}_{5}$ doses and formononetin in $\mathrm{OPl}$, such that the significant and positive influence of $\mathrm{P}_{2} \mathrm{O}_{5}$ doses on the promotion of plant growth is evident, proving that the $\mathrm{P}_{2} \mathrm{O}_{5}$ factor is preponderant in the growth of soybean plants, when compared with the formononetin factor. Thus, in general, higher values for plant height $(\sim 70 \mathrm{~cm})$ were obtained using $80 \mathrm{~kg} \mathrm{ha}^{-1} \mathrm{P}_{2} \mathrm{O}_{5}$ combined with the doses of 0.45 or $1.8 \mathrm{~g} \mathrm{~kg} \mathrm{seed}^{-1}$ formononetin. It is noteworthy that the absence of both factors significantly reduced plant height by $\sim 20 \%$, when compared with the maximum doses of $\mathrm{P}_{2} \mathrm{O}_{5}$ and the doses of 0.45 or $1.8 \mathrm{~g} \mathrm{~kg} \mathrm{seed}^{-1}$ formononetin.

Cordeiro et al. (2015) reported that in Oxisol with intermediate $\mathrm{P}$ doses, there was no interaction between the application of $\mathrm{P}_{2} \mathrm{O}_{5}$ and formononetin for plant height, differing from the results obtained in this study. However, the same author observed individual effects of formononetin, and greater height was obtained with the application of $0.5 \mathrm{mg} \mathrm{seed}$ formononetin in a greenhouse experiment. This occurred because $\mathrm{P}$ is an important constituent of energy compounds (ATP/NADPH), phospholipids, and other esters which play important functions in plant (HAWKESFORD et al., 2012), by influencing proper plant development. 
(A)

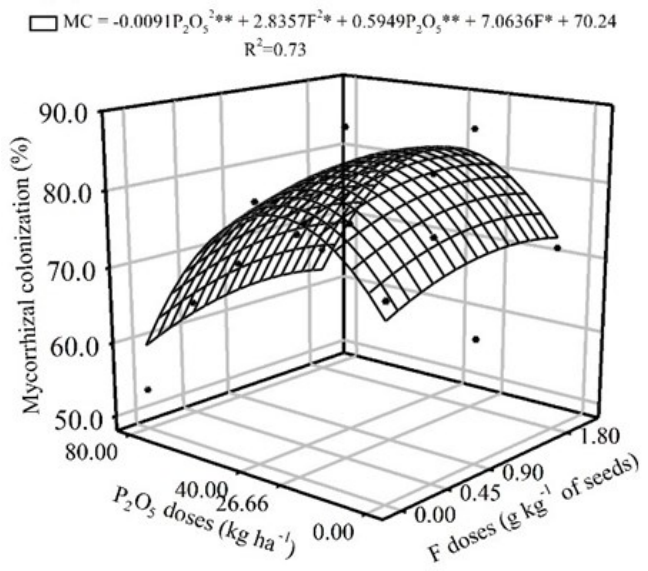

(B)

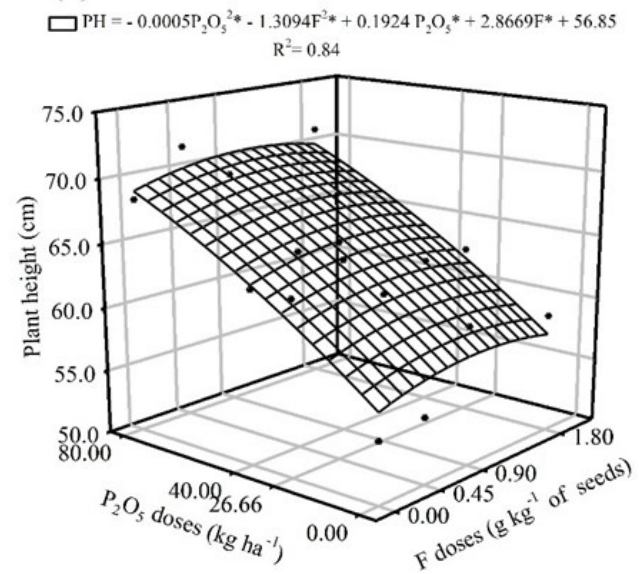

Figure 2. Mycorrhizal colonization (MC) rate in soil with initial intermediate $\mathrm{P}$ content $(\mathrm{A})$ and plant height $(\mathrm{PH})$ in soil with an initial low $\mathrm{P}$ content (B) for soybean plants in function of the isoflavonoid formononetin (F) and phosphorus doses $\left(\mathrm{P}_{2} \mathrm{O}_{5}\right)$.** and * indicate significance at 1 and $5 \%$ by $\mathrm{t}$ test, respectively.

The number of nodules (Figure 3A) and shoot dry biomass (Figure 3C) had a quadratic curve adjustment in relation to the $\mathrm{P}_{2} \mathrm{O}_{5}$ doses, reaching a greater number of nodules and shoot dry biomass with estimated doses of 44.2 and $70 \mathrm{~kg} \mathrm{ha}^{-1} \mathrm{P}_{2} \mathrm{O}_{5}$, respectively. However, there was a reduction in the number of nodules per plant at a dose of $80 \mathrm{~kg} \mathrm{ha}^{-1}$ $\mathrm{P}_{2} \mathrm{O}_{5}$. This was similar to those obtained by Abbasi et al. (2008), who observed in a greenhouse that, the use of a mixture of two strains of Bradyrhizobium japonicum (S377 + S379) and $100 \mathrm{~kg} \mathrm{ha}^{-1} \mathrm{P}_{2} \mathrm{O}_{5}$ reduced the number of nodules, and a dose of $50 \mathrm{~kg}$ $\mathrm{ha}^{-1} \mathrm{P}_{2} \mathrm{O}_{5}$ increased the number of nodules, which is similar to the values obtained in the present study. Thus, it should be noted that $\mathrm{P}$ is essential for the proper development of nodules and for nitrogen fixation, especially in its formation, resulting in a greater number of nodules (KARIKARI; ARKORFUL; ADDY, 2015). The determination of $\mathrm{P}_{2} \mathrm{O}_{5}$ doses, with the aim of reaching the maximum biomass production has proven to be uncertain, ranging from 30 to $100 \mathrm{~kg} \mathrm{ha}^{-1} \mathrm{P}_{2} \mathrm{O}_{5}$ (MABAPA et al., 2010; RIBEIRO et al., 2016).

In general, both AMF and the nitrogen fixing bacteria have a synergistic relationship, although the responsible mechanisms are not yet elucidated. Silva et al. (2017) demonstrated more active soybean nodules when colonized by AMF under field conditions. Studies have shown the effect of formononetin on soybean mycorrhization (CORDEIRO et al., 2015; RIBEIRO et al., 2016). However, in relation to nodulation, the results of these studies are contradictory regarding isoflavonoid application. In the study of Ribeiro et al. (2016), which was carried out in the field, there was no influence of formononetin on the number and weight of nodules of soybean plants; on the other hand, in the study of Cordeiro et al. (2015), which was also carried out in the field, it was found that formononetin application increased the number of nodules.
The increase in $\mathrm{P}_{2} \mathrm{O}_{5}$ doses promoted linear increase in relative chlorophyll content and the number of pods in plants (Figure 3B and D). Tairo and Ndakidemi (2013) obtained results contrary to those of this study, since no effect on the chlorophyll content with $\mathrm{P}$ doses ranging from 0 to $80 \mathrm{~kg} \mathrm{ha}^{-1}$, were found. According to Hawkesford et al. (2012), $\mathrm{P}$ may indirectly contribute to the relative chlorophyll contents of the leaves since it acts in the photosynthesis process, and the nutrient plays important roles in the formation of NADPH and ATP. Fageria, Moreira and Castro (2011) did not find linear growth for the number of pods when increasing doses of $\mathrm{P}_{2} \mathrm{O}_{5}\left(0\right.$ to $\left.120 \mathrm{~kg} \mathrm{ha}^{-1}\right)$ were used in Oxisol with low $\mathrm{P}$ content, which is different from the results of this study.

The number of pods increased linearly in response to the application of formononetin (Figure 3E). These results corroborate those obtained by Cordeiro et al. (2015), in which the positive effect of formononetin application on the number of pods in soybean plants was found. Although the effect of formononetin application is associated with root AMF colonization, its exogenous application can reduce the activities of peroxidase (FRIES; PACOVSKY; SAFIR, 1998) and catalase (LAMBAIS; RÍOS-RUIZ; ANDRADE, 2003), which are enzymes associated with the elimination of reactive oxygen species and contribute to increased number of pods in the soybean plant.

The number of grains per plant (Figure 4A) was adjusted to the quadratic model of the curve, reaching a maximum limit of 222 grains per plant, with the application of an estimated dose of $\sim 66 \mathrm{~kg} \mathrm{ha}^{-1} \mathrm{P}_{2} \mathrm{O}_{5}$. The weight of one thousand grains, grain yield and grain harvest index (Figure 4B-D), despite being significantly influenced by $\mathrm{P}_{2} \mathrm{O}_{5}$ doses, showed better adjustment to the linear regression model. In this sense, the literature reveals that the effect of phosphorus fertilization on the weight of one hundred or one thousand grains is 

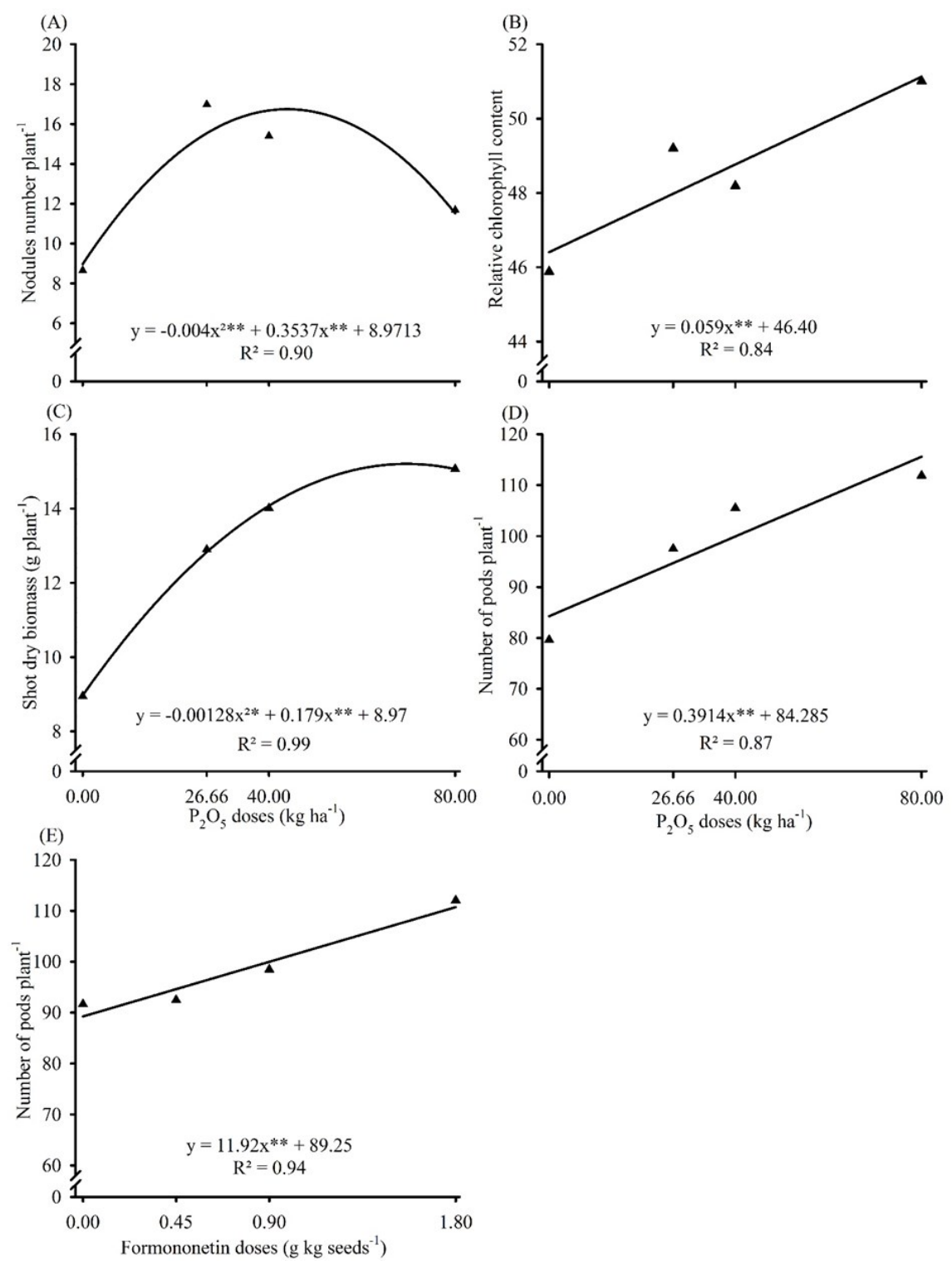

Figure 3. Number of nodules (A), relative chlorophyll content (B), shoot dry biomass (C) and number of pods (D and E) in soybean plants in function of phosphorus doses $\left(\mathrm{P}_{2} \mathrm{O}_{5}\right)$ or isoflavonoid formononetin doses in Oxisol with low initial $\mathrm{P}$. ** and $*$ indicate significance at 1 and $5 \%$ by t test, respectively.

variable (ARAÚJO; SAMPAIO; MEDEIROS, 2005; SOUZA et al., 2014).

The stabilization in number of grains per plant (Figure 4A), occurred with $66 \mathrm{~kg} \mathrm{ha}{ }^{-1} \mathrm{P}_{2} \mathrm{O}_{5}$. However, there was still an increase in the weight (Figure 4B), suggesting that soybean plant prioritizes the transport of assimilates to the existing grains in detriment to new grains. Similarly, the increase in grain yield and grain harvest index in function of the $\mathrm{P}_{2} \mathrm{O}_{5}$ doses is consistent with the linear increases observed in the number of pods per plant (Figure 3D) and weight of one thousand grains (Figure 4B). According to Grant et al. (2001), under P stress, the total number of seeds produced by the plant is reduced as compared to the seed size. Thus, both the abortion of flowers and legumes occur to maintain plant production equilibrium within the available assimilates (BOARD; HARVILLE, 1994).

Soybean grain yield was $\sim 1.200 \mathrm{~kg} \mathrm{ha}^{-1}$ without phosphorus fertilization. However, with the addition of $\mathrm{P}$ to the soil, the agronomic efficiency was $\sim 15 \mathrm{~kg} \mathrm{ha}^{-1}$ grains for each $\mathrm{kg} \mathrm{ha}^{-1} \mathrm{P}_{2} \mathrm{O}_{5}$ applied, which was similar to the value obtained by Valadão Júnior et al. (2008), who worked on increasing $\mathrm{P}_{2} \mathrm{O}_{5}$ doses in the state of Rondônia. In the Cerrado region of Piauí, with low initial P contents in the soil, Alcântara Neto et al. (2010) observed quadratic response to phosphate doses application, and the maximum efficiency was obtained at a dose of 94.8 $\mathrm{kg} \mathrm{ha}{ }^{-1} \mathrm{P}_{2} \mathrm{O}_{5}$, for yield of $2.614 \mathrm{~kg} \mathrm{ha}^{-1}$ grains, which was is similar to the value obtained in this study (2,395 $\mathrm{kg} \mathrm{ha}^{-1}$ grain). 

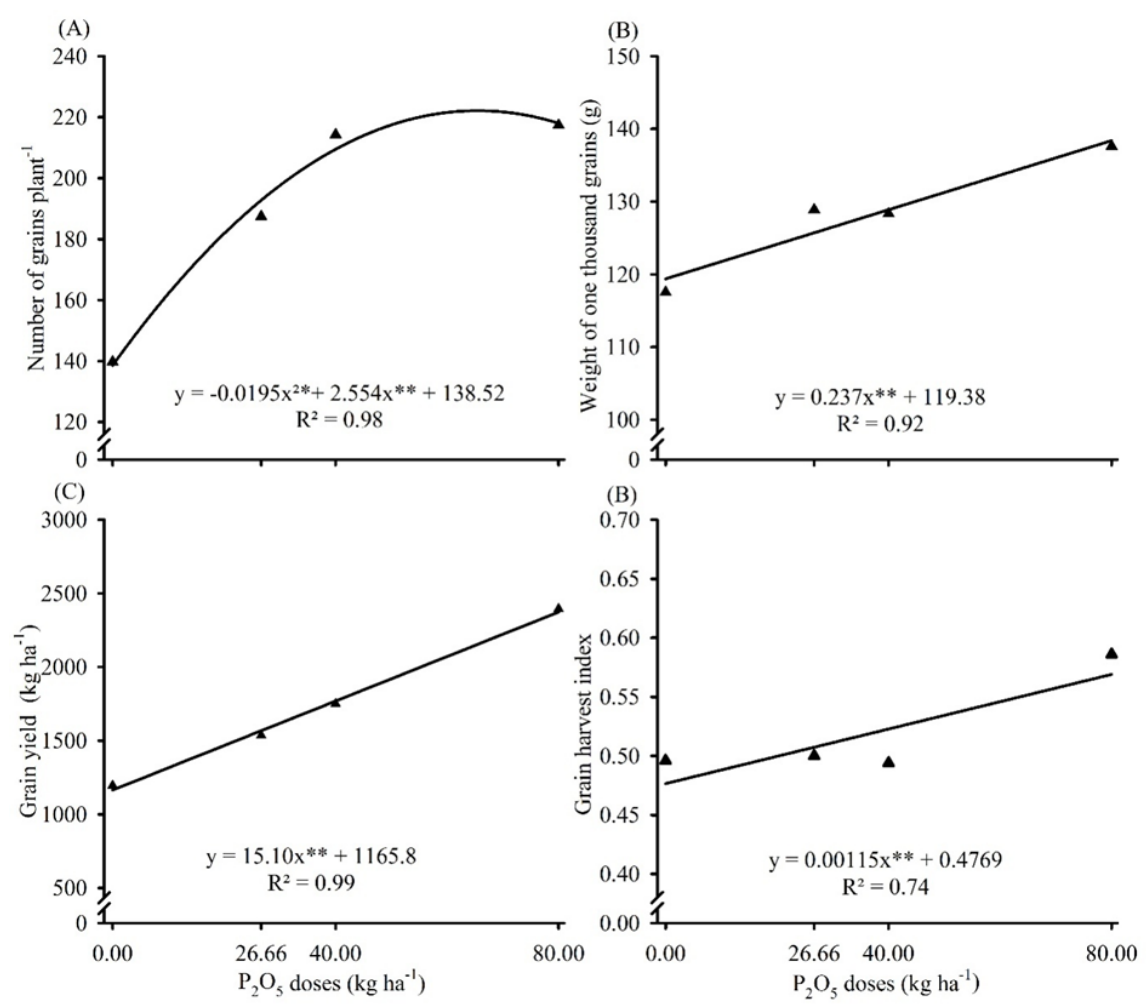

Figure 4. Number of grains per plant (A), weight of one thousand grains (B), grain yield (C) and grain harvest index (D) of soybean in function of phosphorus doses $\left(\mathrm{P}_{2} \mathrm{O}_{5}\right)$ in Oxisol with low initial phosphate, in Cerrado regions of Piauí. ** and * indicate significance at 1 and $5 \%$ by t test.

The adequate $\mathrm{P}$ supply from the beginning of plant growth stimulated root development, formation of the reproductive structures, good formation of legumes and seeds, as well as yield (SHARMA et al., 2013). Therefore, it is possible that during the growth and development of plants, the $\mathrm{P}_{2} \mathrm{O}_{5}$ dose responsible for the maximum yield, together with other nutrients added to the soil, provided the nutritional needs of the crop in a balanced way.

\section{CONCLUSIONS}

The initial phosphorus content influenced soybean grain yield in Oxisol, and the effect of phosphate fertilizer occurred only in soil with low phosphorus content.

In Oxisol with low $\mathrm{P}_{2} \mathrm{O}_{5}$ doses, positive response of phosphate fertilizer was observed for the number of nodules, shoot dry biomass, plant height, relative chlorophyll content, number of pods, number of grains, weight of one thousand grains, grain harvest index and grain yield with the application of $\mathrm{P}_{2} \mathrm{O}_{5}$ doses ranging between 40 and $80 \mathrm{~kg} \mathrm{ha}^{-1}$.

Formononetin application was efficient in the development of soybean in Oxisol with intermediate initial $\mathrm{P}_{2} \mathrm{O}_{5}$ doses, with regards to mycorrhizal colonization rate, and in Oxisol, with low initial $\mathrm{P}_{2} \mathrm{O}_{5}$ doses, there was development of soybean with regards to plant height and number of pods per plant, respectively, at formonetin doses ranging between 0.90 and $1.80 \mathrm{~g} \mathrm{~kg}^{-1}$ seeds.

\section{ACKNOWLEDGEMENTS}

The authors are grateful to the National Research Council (CNPq), the Ministry of Science, Technology and Information (MCT), and PROCAD/ Capes, for financially supporting this project. They also thank the Coordinator for the Improvement of Higher Education Personnel (Capes), for granting scholarships; the $\mathrm{CNPq}$ for research productivity fellowship of F.M.S. Moreira; and to the Federal University of Piauí, for the logistical support.

\section{REFERENCES}

ABBASI, M. K. et al. Application of Bradyrhizobium japonicum and phosphorus fertilization improved growth, yield and nodulation of soybean in the sub-humid hilly region of Azad Jammu and Kashmir, Pakistan. Plant Production Science, Tokyo, v. 11, n. 3, p. 368-376, 2008.

ABDALA, D. B. et al. Surface loading effects on orthophosphate surface complexation at the goethite/ water interface as examined by extended X-ray Absorption Fine Structure (EXAFS) spectroscopy. 
Journal of Colloid and Interface Science, New York, v. 437, s/n., p. 297-303, 2015.

ALCÂNTARA NETO, F. et al. Adubação fosfatada na cultura da soja na microrregião do Alto Médio Gurguéia. Revista Ciência Agronômica, Fortaleza, v. 41, n. 2, p. 266-271, 2010.

ARAÚJO, W. F.; SAMPAIO, R. A.; MEDEIROS, R. D. Resposta de cultivares de soja à adubação fosfatada. Revista Ciência Agronômica, Fortaleza, v. 36, n. 2, p. 129-134, 2005.

BAGO, B.; PFEFFER, P. E.; SHACHAR-HILL, Y. Carbon metabolism and transport in arbuscular mycorrhizas. Plant Physiology, Rockville, v. 124, n. 3, p. 949-958, 2000.

BALZERGUE, C. et al. High phosphate reduces host ability to develop arbuscular mycorrhizal symbiosis without affecting root calcium spiking responses to the fungus. Frontiers in Plant Science, Lausanne, v. 4, s/n., p. 1-15, 2013.

BERRUTI, A. et al. Arbuscular mycorrhizal fungi as natural Biofertilizers: Let's benefit from past successes. Frontiers in Microbiology, Lausanne, v. 6, s/n., p. 1-13, 2016

BOARD, J. E.; HARVILLE, B. G. A criterion for acceptance of narrow-row culture in soybean. Agronomy Journal, Madison, v. 86, n. 6, p. 11031106, 1994.

COMISSÃO DE FERTILIDADE DO SOLO DO ESTADO DE MINAS GERAIS - CFSEMG. Recomendações para o uso de corretivos e fertilizantes em Minas Gerais. $5^{\text {a }}$ Aproximação. Viçosa, MG: CFSEMG, 1999, 322 p.

CORDEIRO, M. A. S. et al. Mycorrhization stimulant based in formononetin associated to fungicide and doses of phosphorus in soybean in the Cerrado. Bioscience Journal, Uberlândia, v. 31, n. 4, p. 1062-1070, 2015.

DAVIES, F. T.; CALDERON, C. M.; HUAMAN, Z. Influence of arbuscular mycorrhizae indigenous to Peru and a flavonoid on growth, yield, and leaf elemental concentration of 'Yungay' potatoes. HortScience, Alexandria, v. 40, n. 2, p. 381 - 385, 2005.

FAGERIA, N. K.; MOREIRA, A.; CASTRO, C. Response of soybean to phosphorus fertilization in Brazilian Oxisol. Communications in Soil Science and Plant Analysis, London, v. 42, n. 22, p. 27162723, 2011.

FERREIRA, E. B.; CAVALCANTI, P. P.;
NOGUEIRA, D. A. ExpDes: Experimental designs package. $\mathrm{R}$ package version 1.1.2, 2013.

FRIES, L. L. M.; PACOVSKY, R. S.; SAFIR, G. R. Influence of phosphorus and formononetin on isozyme expression in the Zea mays - Glomus intraradices symbiosis. Physiologia Plantarum, Sweden, v. 103, n. 2, p. 172 - 180, 1998.

GIOVANETTI, M.; MOSSE, B. An evaluation of techniques to measure vesicular arbuscular mycorrhizal infection roots. New Phytologist, Lancaster, v. 84, n. 3, p. 489-500, 1980.

GRANT, C. A. et al. The importance of early season phosphorus nutrition. Canadian Journal of Plant Science, Ottawa, v. 81, n. 2, p. 211-224, 2001.

HAWKESFORD, M. et al. Functions of macronutrients. In: MARSCHNER, P. (Ed.). Mineral nutrition of higher plants. New York: Elsevier, 2012. cap. 6, p. 135-189.

KARIKARI, B.; ARKORFUL, E.; ADDY, S Growth, nodulation and yield response of cowpea to phosphorus fertilizer application in Ghana. Journal of Agronomy, Faislabad, v. 14, n. 4, p. 234-240. 2015 .

KÖPPEN, W. Grundriss der klimakunde. Berlin: Walter de Guyter, 1931. 390 p.

LAMBAIS, M. R.; RÍOS-RUIZ, W. F.; ANDRADE, R. M. Antioxidant responses in bean (Phaseolus vulgaris) roots colonized by arbuscular mycorrhizal fungi. New Phytologist, Lancaster, v. 160, n. 2, p. 421-428, 2003

LOPES, A. S.; GUILHERME, L. R. G. A career perspective on soil management in the Cerrado Region of Brazil. In: SPARKS, D. (Ed.). Advances in Agronomy 137. Cambridge: Academic Press, 2016. p. $1-72$.

MABAPA, P. M. et al. Effect of phosphorus fertilizer rates on growth and yield of three soybean (Glycine max) cultivars in Limpopo Province. African Journal of Agricultural Research, Ebène, v. 5 , n. 19 , p. $2653-2660,2010$.

MARSCHNER, H.; DELL, B. Nutrient uptake in mycorrhizal symbiosis. Plant and Soil, Dordrecht, v. 159, n. 1, p. 89-102, 1994

MURPHY, J.; RILEY, J. P. A modified single solution method for the determination of phosphate in natural waters. Analytica Chimica Acta, Amsterdam, v. 27, s/n., p. 31-36, 1962.

NOURI, E. et al. Phosphorus and nitrogen regulate 
arbuscular mycorrhizal symbiosis in Petunia hybrida. PLoS ONE, San Francisco, v. 10, n. 4, p. 114, 2014.

NOVAIS, R. F.; SMYTH, T. J. Fósforo em solo e planta em condições tropicais. Viçosa, MG: UFV, 1999. $399 \mathrm{p}$.

PHILLIPS, J. M.; HAYMAN, D. S. Improved procedures for clearing roots and staining parasitic and vesicular-arbuscular mycorrhizal fungi for rapid assessment of infection. Transactions of the British mycological Society, London, v. 55, n. 1, p. 158-61, 1970.

PONTES, J. S. et al. Diversity of arbuscular mycorrhizal fungi in the Brazilian's Cerrado and in soybean under conservation and conventional tillage. Applied Soil Ecology, Amsterdam, v. 117-118, s/n., p. 178-189, 2017.

RIBEIRO, P. R. A. et al. Formononetin associated with phosphorus influences soybean symbiosis with mycorrhizal fungi and Bradyrhizobium. Bioscience Journal, Uberlândia, v. 32, n. 4, p. 940-951, 2016.

SHARMA, S. B. et al. Phosphate solubilizing microbes: sustainable approach for managing phosphorus deficiency in agricultural soils. SpringerPlus, London, v. 2, n. 1, p. 1-14, 2013.

SILVA, J. S. et al. Formononetin stimulates mycorrhizal fungi colonization on the surface of active root nodules in soybean. Symbiosis, Maharashtra, v. 71, n. 1, p. 27-34, 2017.

SINGH, S. K.; REDDY, V. R. Response of carbon assimilation and chlorophyll fluorescence to soybean leaf phosphorus across $\mathrm{CO}_{2}$ : alternative electronsink, nutrient efficiency and critical concentration. Journal of Photochemistry and Photobiology B: Biology, Lausanne, v. 151, n. 1, p. 276-284, 2015.

SMITH, S. E. et al. Roles of arbuscular mycorrhizas in plant phosphorus nutrition: interactions between pathways of phosphorus uptake in arbuscular mycorrhizal roots have important implications for understand ingand manipulating plant phosphorus acquisition. Plant Physiology, Rockville, v. 153, n. 3, p. 1050-1057, 2011.

SOUZA, J. R. et al. Efficiency of coated match with polymers in soybean. Acta Iguazu, Cascavel, v. 3, n. 4, p. 1-9, 2014.

SOUZA, T. Handbook of arbuscular mycorrhizal fungi. Switzerland: Springer International Publishing, 2015. 128 p.
TAIRO, E. V.; NDAKIDEMI, P. A. Bradyrhizobium japonicum inoculation and phosphorus supplementation on growth and chlorophyll accumulation in Soybean (Glycine $\max$ L.). American Journal of Plant Sciences, Irvine, v. 4, n. 12, p. 2281-2289, 2013.

TEIXEIRA, R. S. et al. Organic acid coated-slowrelease phosphorus fertilizers improve $\mathrm{P}$ availability and maize growth in a tropical soil. Journal of soil science and plant nutrition, Temuco, v. 16, n. 4, p. 1097-1112, 2016.

VALADÃO JÚNIOR, D. D. et al. Adubação fosfatada na cultura da soja em Rondônia. Scientia Agraria, Curitiba, v. 9, n. 3, p. 369-375, 2008. 